\title{
Institutional trajectory for diffusing on-site wastewater treatment in urban china
}

\author{
Li Li, Christian Binz, Yonglong Lu, Bernhard Truffer and Yajuan Shi
}

\begin{abstract}
Urban water scarcity has been an issue for a long time in China while water pollution has attracted more and more attention over the last two decades. Recently, on-site wastewater treatment (OST) has been proposed as a meaningful alternative to deal with both water pollution and water scarcity in cities in a more sustainable way. However, the diffusion of such an OST system is still slow and often hindered by mismatched regulation, city planning and policy interventions. This paper is intended to explore potential solutions from institutional and governance perspectives. Based on expert interviews and in-depth analysis of an OST system in Kunming, an improved trajectory for diffusing OST in urban China is developed, which includes reformed decision-making and operational procedures, role transition of relevant stakeholders, and improved financing mechanisms. The results might give some suggestions for the transition of urban water management in other newly industrializing countries.
\end{abstract}

Li Li

Yonglong Lu (corresponding author)

Yajuan Shi

State Key Laboratory of Urban and Regiona Ecology,

Research Center for Eco-Environmental Sciences, Chinese Academy of Sciences,

100085 Beijing,

China

E-mail: yllu@rcees.ac.cn

Christian Binz Bernhard Truffer

Cirus - Innovation Research in Utility Sectors,

Eawag, Swiss Federal Institute of Aquatic Science and Technology,

8600 Dübendorf,

Switzerland

Key words | China, on-site wastewater treatment, technology diffusion, urban water management

\section{INTRODUCTION}

China is experiencing the greatest wave of urbanization in history (Browder et al. 2007). In addition to an uneven temporal and spatial distribution of water resources and limited water supplies in many areas (He et al. 200I; Chu et al. 2004), China also has some of the most polluted rivers in the world. How can China sustain and improve urban water conditions as it undergoes rapid urbanization, makes the transition to a market economy and confronts extreme water resource degradation? On-site wastewater treatment (OST) has been proposed as a potential alternative to the traditional centralized system, as it has advantages especially in dealing with rapid urbanization and water scarcity (Wilderer 2004; Fane \& Fane 2005; Gikas \& Tchobanoglous 2009; Massoud et al. 2009). It manages wastewater as close as possible to where it is generated and to where its potential reuse is located (Lens \& Lettinga 200I; van Voorthuizen et al. 2005). In comparison, the centralized wastewater treatment system uses a larger amount of freshwater for the waste transportation, and water recycling is only feasible with the buildup of a very expensive recycling water pipe network. OST thus has advantages in terms of economic, environmental and technological benefits (Balkema et al. 2002; van Voorthuizen et al. 2005; Chung et al. 2008; Sabry
20I0). About 20-30\% of wastewater in the USA and Europe and more than $30 \%$ in Japan is treated by OST (Chen 2004; Water Environment Research Foundation 2007), while in China only 13.2 and 5\% of wastewater in designated cities and county-towns is treated by OST (Ministry of Housing and Urban-rural Development of People's Republic of China 2008). There are still many technical, institutional, and financial challenges (Browder et al. 2007).

It is crucial to define trajectories for diffusing OST because the wastewater field is in a typical socio-technical lock-in situation (Unruh \& Carrillo-Hermosilla 2006). The conventional centralized wastewater sector is dominated by natural monopolies created by extended sewage networks, sunk costs in long-living infrastructure, hidden subsidies and large, inflexible utilities. This organizational structure usually develops in a very coherent path of incremental technological innovation and only limited changes in the social context (Markard 20II). In order to introduce a new concept like OST into this sector, a systemic innovation or a 'sustainability transition' is needed (Elzen \& Wieczorek 2005), together with a co-evolution in the technological paradigms, socio-institutional embedding and the dominant business and user practices. In such systemic 
innovations, a complex set of relevant stakeholders (government, academia, users, planning bureaus and industry) have to be orchestrated and be introduced to interactive learning about a new way of doing things. Defining scenarios or feasible trajectories for a transition can help these actors to develop a new joint vision for the future, which is potentially more sustainable and efficient (Dominguez et al. 2009). In this paper such a trajectory will be developed based on an institutional analysis of the contexts that define the current and future implementation potential of OST in China.

\section{$\overline{\text { METHODOLOGY }}$}

A trajectory for environmental technology diffusion is an institutional model involving multiple actors and institutional settings that define regulations and governance structure, economic and financial incentive schemes, service and business models, and wider cognitive and normative institutional structure of a new technology. Organizational mapping was used to unpack the 'black box' of decision making and implementation processes of OST in China in this paper. It is a visual illustration that combines mapping and tracing techniques to illustrate and analyze flows of resources, information, and decision making (Holland 2007). The analysis is based on two organizational instruments: a static map and a process map (Dani 2003). Static mapping is used to illustrate the existing process and the participants in the OST sector. It includes an organizational flow chart that maps the formal links among all relevant stakeholders. Process mapping identifies formal and informal rules and procedures. It relates resources to activities, material flows, and decision-making processes, and identifies bottlenecks and constraints.

The data used for this analysis was collected in an iterative process of semi-structured and open-ended interviews with 32 experts and seven in-depth investigations of OST projects in Kunming. The interviews covered senior experts in water purification, facility planning and design, policy making, facility management and market development from Beijing and Kunming. Organizational manuals, existing organizational charts, and organograms were also primary sources of mapping data.

\section{$\overline{\text { OST DIFFUSION IN KUNMING }}$}

Kunming is located in the southwest of China. Its city lake Dianchi is one of most seriously polluted lakes in China with the water quality inferior to grade $\mathrm{V}$ in terms of the national water quality standards. (According to environmental quality standard for surface water of the People's Republic of China (GB3838-2002), the water environment quality is classified into five grades, from grade I to grade $\mathrm{V}$. Grade I is the best quality, which is suitable for protected areas of water resources and national nature reserves. Grade V is the worst and is only suitable for agricultural or general landscape use. The water quality standards are established based on 24 physical, chemical and bacteriological parameters.) With the urban expansion, the construction of the pipeline network could not meet the demand. Lots of the wastewater could not be connected to the sewage pipeline to be treated in the centralized treatment plant. Moreover, Dianchi basin is also a water-scarce area. Available water resources per capita are only $270 \mathrm{~m}^{3}$ per year, which is much lower than that in Beijing and Tianjin.

To solve the problems of water pollution and water shortage, OST was introduced to Kunming in 1998. However, the diffusion was slow at the beginning, and there were only a few dozen OST facilities in Kunming until 2004. Since 2004, the municipal government has implemented a series of policies to encourage the construction and operation of OST (Table 1). More than 240 OST facilities were installed in Kunming up to 2010. OST has been widely applied in hotels, school campuses, resident districts, bus parking lots and so on. The investment in an OST facility is about $0.5-0.8 \mathrm{CNY}$ (Chinese yuan) $/ \mathrm{m}^{3}$ treatment capacity, and the operation cost is about $1.2-1.5 \mathrm{CNY} / \mathrm{m}^{3}$ wastewater. With the subsidy from the municipal government, technology support from an environmental technology company, and supervision from the Water Authority, most facilities can continuously run in good condition. The institutional system in Kunming thus presents an interesting case for diffusing the OST system in China.

\section{INSTITUTIONAL SYSTEM OF OST IN KUNMING}

Based on the field investigation and expert interview, an organizational map of OST implemented in Kunming can be drawn. The institutional system of OST in Kunming can be divided into six parts (Figure 1). The first part is about planning decision making (Figure 1 part (1). In terms of local water resource availability, water saving plans and OST, policies are proposed by the Municipal Water Authority to Municipal Congress. For example, the property owners are allowed to treat wastewater with their own facilities even after the 
Table 1 | Policies for OST diffusion in Kunming

\begin{tabular}{|c|c|c|}
\hline Areas & Implementation bodies & Objectives \\
\hline \multicolumn{3}{|l|}{ Legislation } \\
\hline $\begin{array}{l}\text { Administrative regulation for urban water } \\
\text { saving in Kunming }\end{array}$ & Municipal Congress & Specify the water reclamation policy \\
\hline $\begin{array}{l}\text { Implementation measures for special funding } \\
\text { for water reclamation in Kunming }\end{array}$ & Municipal government & Guarantee funding for water reclamation \\
\hline $\begin{array}{l}\text { Special planning for wastewater reclamation in } \\
\text { urban areas }\end{array}$ & $\begin{array}{l}\text { Municipal government, Water } \\
\text { Authority }\end{array}$ & $\begin{array}{l}\text { Give classified guidance to different areas to } \\
\text { promote the development of water reclamation }\end{array}$ \\
\hline \multicolumn{3}{|l|}{ Financial support } \\
\hline Construction subsidy & $\begin{array}{l}\text { Municipal government, Water } \\
\text { Authority }\end{array}$ & $\begin{array}{l}\text { Encourage the construction of reclamation facilities } \\
\text { on existing and/or new sites }\end{array}$ \\
\hline Operation subsidy & $\begin{array}{l}\text { Municipal government, Water } \\
\text { Authority }\end{array}$ & $\begin{array}{l}\text { Encourage good operation and maintenance of } \\
\text { recycling facilities }\end{array}$ \\
\hline \multicolumn{3}{|l|}{ Technical support } \\
\hline Guideline for water reclamation facility design & $\begin{array}{l}\text { Water Authority, Kunming } \\
\text { University of Technology }\end{array}$ & Standardize the facility design \\
\hline $\begin{array}{l}\text { Guideline for water reclamation facility } \\
\text { management and operation }\end{array}$ & $\begin{array}{l}\text { Water Authority, Kunming } \\
\text { University of Technology }\end{array}$ & $\begin{array}{l}\text { Standardize the operation and management } \\
\text { procedures }\end{array}$ \\
\hline Management training & Water Authority & Improve the management of OST operators \\
\hline
\end{tabular}

municipal sewage network was extended to their district, and the property owners are encouraged to construct OST through subsidies or exemptions from the wastewater tariff. After the Municipal Congress approves the proposals, implementation, supervision, and technology standards/ guidelines are defined by the Municipal Water Authority with the technical assistance of a local design institute, research institute and environmental technology companies. The Municipal Water Authority plays an important role in the planning and selection of a development route for centralized and OST and reuse.

The second part is about the project decision making (Figure 1 part (2). In Kunming, the real-estate companies and the property owners are the main agents in constructing OST. As the Municipal Congress has previously approved a subsidy policy for construction and operation of such facilities, all facility owners can apply for it. The Municipal Water Authority assesses the applications and decides whether to subsidize specific projects and how much the subsidy will be. The realestate companies usually don't have expertise in wastewater treatment and reuse. Hence, some have to get technical support from professional design institutes or environmental technology companies to select the appropriate technology.

Other four parts, (1) construction and operation, (2) financial support, (3) technological support, and (4) supervision, are related to construction, operation and maintenance of OST. Taking the residential districts as an example, the real-estate companies construct the OST. They usually authorize a property service company to take charge of daily operation. If the residents want to use reclaimed water, for example, for toilet flushing, they have to directly pay the property service company. Meanwhile, the users also have to pay the wastewater tariff to the government according to the law (Figure 1 part (3). In order to compensate for the investment and operational costs, the real-estate company and the property service company can apply to the Municipal Water Authority for a subsidy. The subsidy budget is proposed to the Municipal Congress for approval and allocated by the Bureau of Finance (Figure 1 part (4). The amount of construction subsidy is determined by the Water Authority according to the treatment capacity, while the operation subsidy is determined according to the quality and quantity of reclaimed water that the facility generates. An automatic measuring instrument can continuously monitor the quantity of reclaimed water. In addition, water quality is monitored from time to time by an independent monitoring organization which is certified by the Water Authority or Environmental Protection Bureau (Figure 1 part (5). The design institute, research institute and environmental technology companies provide technical support and after-sale service to the operators for daily operation and emergency response (Figure 1 part ๔)). 


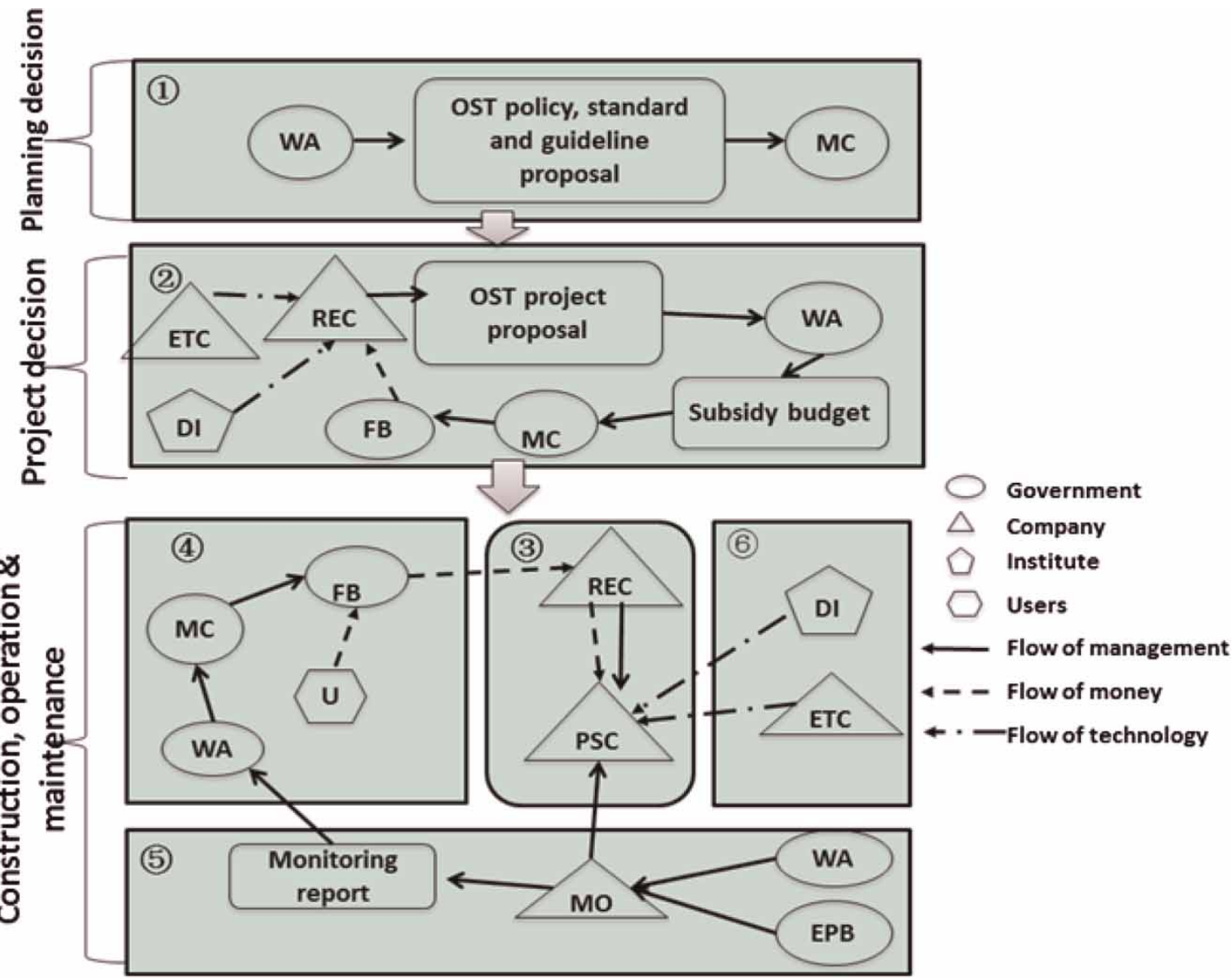

Figure 1 | Institutional system of OST in Kunming. WA: Water Authority; MC: Municipal Congress; FB: Finance Bureau; REC: real estate company; ETC: environmental technology company; DI: design institute; PSC: property service company; U: users; EPB: Environmental Protection Bureau; MO: monitoring organization.

\section{Challenges in Kunming's OST system}

Even though a great success in OST diffusion has been achieved in Kunming, there are still some challenges. Firstly, OST in Kunming is a trial. Its planning has not been integrated into the urban planning yet. According to the current law and regulation, it is a priority choice for the wastewater to be transported to the centralized plant if there is one nearby. Many OST owners worry that their OST facilities may have to be abandoned if the sewer network is extended to their areas in the future.

Secondly, subsidy is not a long-term solution to the capital shortage in industry development. The centralized wastewater treatment has already developed mature business models, such as BOT (build-operate-transfer) and TOT (transfer-operate-transfer), and the financial channel is diverse, including direct investment and indirect loan from investment companies, banks and other organizations. However, the business model for OST is still unclear.
Property owners or the real-estate companies are the only investors in most of the OST projects in Kunming. Most companies are not interested in OST projects since there is no clear policy about the charge for wastewater treatment and recycling by OST.

Thirdly, the technologies applied in the OST system are much more diversified than that in the centralized plants. Most large environmental engineering companies are not interested in OST projects, and only some emerging and small sized companies are willing to engage in the business. The OST technology market is highly segregated and disordered. There is no independent third party certification body to assess various OST technologies. Some small companies may thus overstate the functioning and performance of their technologies, which prevents the consumers from choosing an appropriate technology.

Finally, the management of OST in Kunming is still dispersed. Many property service companies so far only serve a few buildings and families; so they cannot afford the high 
cost of a large operation, especially for emergency response. It is thus hard for them to scale up their activities, improve management and achieve professional operation. To a large extent, this seriously hinders the industrialization, standardization and further institutionalization of the sector.

\section{IMPROVE TRAJECTORY FOR OST DIFFUSION IN CHINA}

Despite the preliminary success in diffusing OST systems in Kunming, the context still needs to be improved to overcome the systemic innovation challenges. By integrating the strengths of potential trajectories and experiences from the case study in Kunming, the institutional system of OST in China is developed.

\section{Institutional system of OST in China}

To promote OST diffusion in China, the plan decision part, project decision part, construction and operation part, and financial support part are improved based on the system of Kunming. The water-saving planning and policies about on-site wastewater management should be integrated into urban planning. The Commission of Urban Planning, the Environmental Protection Bureau and the Water Authority should work together to identify which areas of the city should apply centralized wastewater treatment, and which areas could develop OST according to geographic conditions, water distribution, environmental capacity and the distribution of potential reclaimed-water users. This information could guide the planning and construction of the treatment facilities. The property ownership of residential districts is always dispersed, and it is difficult to replace the existing centralized system in old residential districts. Thus, the Commission of Housing and Urban-rural Development could propose policies such as certification or subsidy to encourage constructing OST facilities together with the large buildings in new residential districts (Figure 2 part (1).

Environmental investment companies can be introduced, to invest and construct OST, once the property owner or real-estate company wants to implement an OST

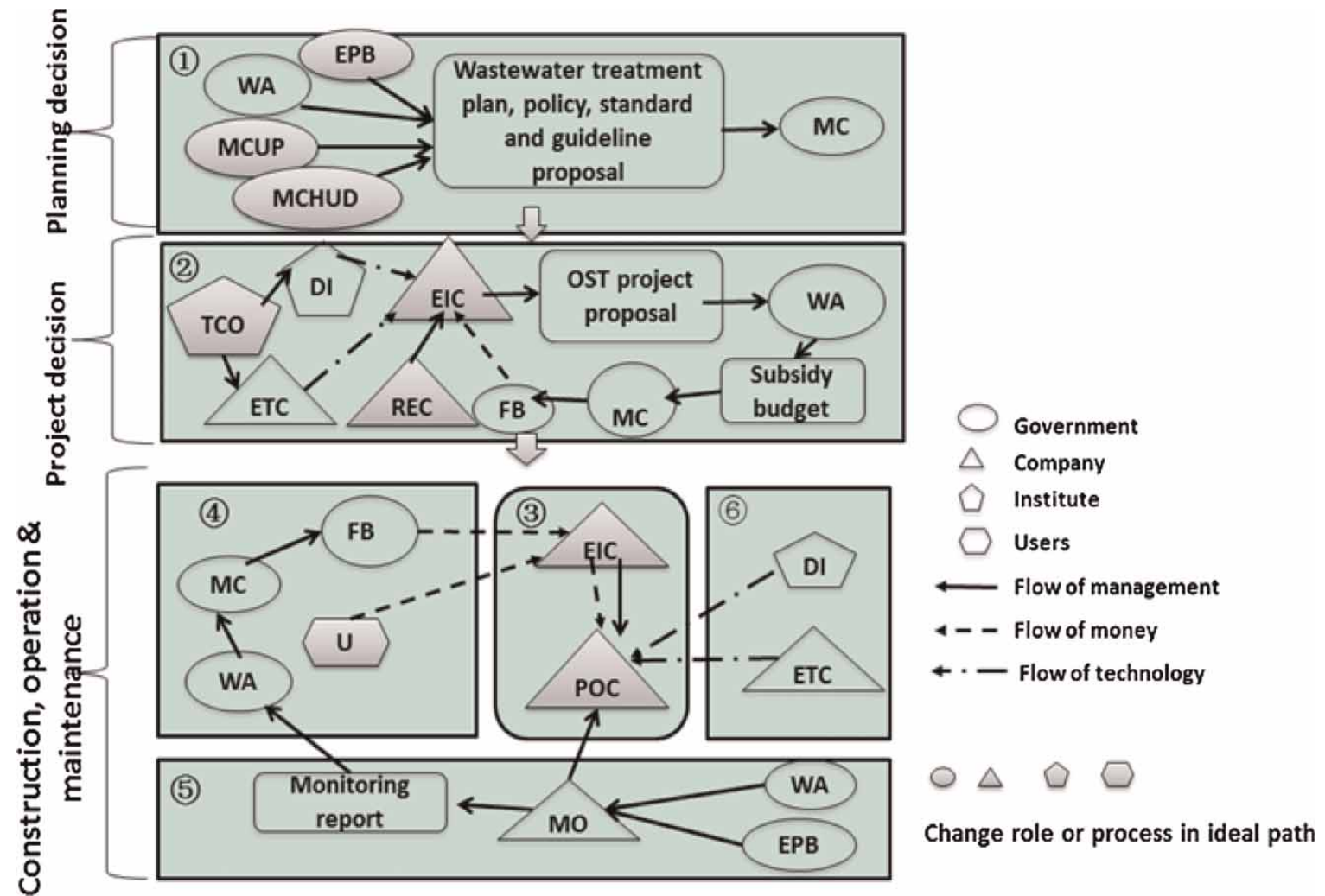

Figure 2 Improved institutional system of OST in urban China. WA: Water Authority; MC: Municipal Congress; FB Finance Bureau; REC: real estate company; ETC: environmental technology company; DI: design institute; U: users; EPB: Environmental Protection Bureau; MO: monitoring organization; MCUP: Municipal Commission of Urban Planning; MCHUD: Municipal Commission of Housing and Urban-rural Development; EIC: environmental investment company; TCO: technology certification organization; POC: professional operation company. 
facility. They can also apply for the subsidy from the government. In addition, an independent technology certification organization is necessary to assess the performance of the water treatment technologies offered by different companies, and help the design institute and environmental companies to choose appropriate technologies. This organization should be fully independent, and the assessment cost be borne by the technology companies (Figure 2 part (2).

Environmental investment companies gain a profit from selling the reclaimed water to the end users, such as families in the residential districts. Therefore, there is a direct incentive for them to put pressure on professional operation companies to keep the OST systems running and to maintain in good shape. In this way, the capital shortage could be solved, and a strict monitoring system would ensure professional operation and maintenance. Users that do not discharge the wastewater into the municipal sewage system could be exempt from paying the wastewater tariff. Since water recycling would save fresh water, the water resource tax could instead be applied to improve the monitoring and control system for dispersed OST facilities (Figure 2 parts (3) and (4)).

\section{Role transition of relevant stakeholders}

To promote OST diffusion, new stakeholders should be involved, while the roles and responsibilities of some stakeholders should be changed (Table 2). In Kunming, the real estate companies are the major promoters of OST facilities. They like to invest in OST because it could reduce their freshwater consumption and thus reduce freshwater bills, or because it could increase their competitiveness in the real estate market. To improve the OST diffusion in China, the environmental investment companies should be introduced to this new business. The real estate companies only decide whether to build the system or not. Once they decide to build the facility, they would get investment companies involved. The investment companies would bear the costs for installing OST facilities and make profits from selling recycled water. The Environmental Protection Bureau,

Table 2 Responsibilities of stakeholders in Kunming and improved OST system

Stakeholder

Environmental Protection Bureau

Water Authority

Municipal Commission of Urban Planning

Municipal Congress

Finance Bureau

Municipal Commission of Housing and Urban-rural Development

Design/research institute

Environmental investment companies

Users

Environmental technology companies

Real estate companies

Property service companies

Monitoring organization

Technology certification organizations

Professional operation companies
Responsibility in Kunming OST

Not involved

Propose and implement policies, supervise subsidies

Not involved

Approve OST policy and subsidies

Allocate investment and operation subsidies

Not involved

Offer technical support in the planning process

Not involved

Pay wastewater treatment charge and reclaimed-water fee

Offer OST systems, technical support and after-sale service

Implement OST facilities into new construction projects

Operate and maintain the OST facilities

Monitor effluent quality

Not involved

Not involved
Responsibility in improved OST

Take part in urban water planning, supervise effluent monitoring

Same as Kunming

Integrate decentralized wastewater treatment into urban planning

Approve integrated planning, policy and subsidies

Same as Kunming

Propose policies to promote decentralized recycling in buildings or residential districts

Offer technical support and after-sale service

Invest in facility construction and OST industry

Pay only reclaimed-water fee

Same as Kunming, but with mass-produced products

Authorize environmental investment companies to invest or construct OST systems

Not involved in maintenance and service

Same as Kunming

Offer professional technology assessment and certification for OST systems

Offer professional daily operation and maintenance, emergency response 
Commission of Urban Planning, environmental investment companies, property owners, and environmental technology companies would have opportunities to take part in the integrated planning of wastewater treatment and in the selection of the technology. The benefits and risks of OST to other stakeholders are uncertain, and these stakeholders would accordingly have a low decision power to influence the selection of the treatment technology.

When referring to the construction, operation and maintenance of OST, government is the rule-designer, and its major responsibility would be not only supervision of the effluent, but also to offer proper incentives, especially economic incentives, to encourage the operation and maintenance of OST. The environmental technology companies would offer various treatment technology and equipment systems, and help to train operation workers. Professional operation companies would take charge of daily operation and maintenance of the dispersed facilities. They would train operation workers and engineers, check the facilities at regular intervals, and offer technological support at any time. Technology certification organizations would evaluate the OST technologies before they enter the market and gain credit from the consumers. An independent monitoring organization should monitor the effluent quality at regular intervals, and thereby support the supervision and policy implementation of the government.

\section{Policy improvement}

Wastewater tariffs are a major source of wastewater treatment funds in China. They are traditionally managed by the government and allocated to support the construction and operation of sewage and centralized wastewater treatment plants. The wastewater tax is charged in terms of the freshwater consumption rather than the amount of wastewater discharged into the sewage system in many cities. Therefore, the property owners or operators of OST not only need to pay the treatment and recycling cost for their own facilities, but also have to hand in wastewater treatment tax to the government. Thus, our interviewees from OST companies claimed that reforming current wastewater tariff policy and avoiding double charges would be central for encouraging the application of OST systems in China. Wastewater recycling could save much investment and maintenance cost compared with other ways of new water resource development, such as sea water desalination, inter-basin water transfer or exploitation of deep phreatic water. For example, the total investment and operation cost of reclaimed water for OST systems in Beijing is about 1.74$2.41 \mathrm{CNY} / \mathrm{m}^{3}$ (based on our investigation of 25 OST systems in Beijing) (Li 20I2), while the cost of sea water desalination is at least $4 \mathrm{CNY} / \mathrm{m}^{3}$ in China (Tan et al. 2007), and the cost of water transfer in the South to North Project is more than $8 \mathrm{CNY} / \mathrm{m}^{3}$ (Qin et al. 20Io). In this case, allocating more water resource funds to support OST could stimulate the construction and operation of recycling facilities.

The reclaimed water prices in most cities are still too low, for example $1 \mathrm{CNY} / \mathrm{m}^{3}$ in Beijing, while the cost of most dispersed recycling facilities is more than $1.5 \mathrm{CNY} /$ $\mathrm{m}^{3}$, and the freshwater price is $4 \mathrm{CNY} / \mathrm{m}^{3}$. If the investors or operators can't balance the costs and revenues, it will be hard to encourage more companies to take part in the OST business, and difficult to guarantee the sustainable development of the treatment industry. Therefore, proper reclaimed-water prices are critical to encourage more investment companies or social capital to get involved in OST. Reasonable reclaimed-water prices should be lower than the freshwater price and higher than the treatment and recycling cost of the OST. Under such conditions, most users will be willing to use reclaimed water to save money, and the investors could make profits from water recycling.

Moreover, as the sewage system extends, the property owners should not be forced to transport the wastewater to the centralized wastewater treatment plants and should be allowed to continue to treat and recycle the wastewater by OST facilities, as long as the effluent from OST facilities can reach relevant environmental standards.

\section{$\overline{\text { CONCLUSIONS }}$}

This paper presented an institutional perspective for OST diffusion in China. Water conservation and environmental protection are helpful to promote the OST diffusion in urban China, and Kunming city gives a good example for this diffusion trajectory. Clear legal status, reasonable financing, and proper management and supervision are critical to the success of Kunming. However, there are also some challenges for OST system development in Kunming, such as disintegration with urban planning, lack of business model, disordered technology market, and shortage of professional and high-quality operation personnel. Through expert interviews and an in-depth case study in Kunming, an improved trajectory for diffusing OST in China is developed, which includes reformed decision-making and operational procedures, role transition of relevant stakeholders, and improvement of financing mechanisms.

Many countries in the world face both water scarcity and water pollution, especially in developing countries. More alternatives in wastewater treatment, such as OST and urine 
separation toilet, can help overcome the technological lock-in in urban water management and achieve sustainable development. If OST in urban China embarks on a development trajectory that takes the institutional context of new technologies into account, it may provide important directions for the transition of urban water management in other countries.

\section{ACKNOWLEDGEMENT}

The authors are grateful for the support provided by the SinoSwiss cooperation project between the Research Center for Eco-Environmental Sciences, Chinese Academy of Sciences, and the Swiss Federal Institute of Aquatic Science and Technology (Eawag) with Grant No.GJHZ0910 and the National Key Technology R\&D Program with Grant No. 2008BAC32B07. We would also like to thank Prof. Theo Beckers for his extremely helpful comments. Last but not least, we thank Prof. Tony Fuller for polishing the language.

\section{REFERENCES}

Balkema, A. J., Preisig, H. A., Otterpohl, R. \& Lambert, F. J. D. 2002 Indicators for the sustainability assessment of wastewater treatment systems. Urban Water 4 (2), 153-161.

Browder, G. J., Xie, S., Kim, Y., Gu, L., Fan, M. \& Ehrhardt, D. 2007 Stepping Up: Improving the Performance of China's Urban Water Utilities. World Bank, Washington DC.

Chen, J. 2004 Policy and experiences on administration of decentralized wastewater treatment system in USA. China Water \& Wastewater 20 (6), 104-106 (in Chinese).

Chu, J., Chen, J., Wang, C. \& Fu, P. 2004 Wastewater reuse potential analysis: implications for China's water resource management. Water Research 38 (11), 2746-2756.

Chung, G., Lansey, K., Blowers, P., Brooks, P., Ela, W., Stewart, S. \& Wilson, P. 2008 A general water supply planning model: evaluation of decentralized treatment. Environmental Modeling \& Software 23 (7), 893-905.

Dani, A.A. 2003 Social Analysis Sourcebook: Incorporating Social Dimensions into Bank-Supported Projects, World Bank, Washington, DC.

Dominguez, D., Worch, H., Markard, J., Truffer, B. \& Gujer, W. 2009 Closing the capability gap: strategic planning for the infrastructure sector. California Management Review 51, 30-50.

Elzen, B. \& Wieczorek, A. 2005 Transitions towards sustainability through system innovation. Technological Forecasting and Social Change 72 (6), 651-661.

Fane, A. G. \& Fane, S. A. 2005 The role of membrane technology in sustainable decentralized wastewater systems. Water Science and Technology 51 (10), 317-325.
GB3838-2002 Environmental Quality Standard for Surface Water. http://english.mep.gov.cn/standards_reports/standards/ water_environment/quality_standard/200710/t20071024_ 111792.htm.

Gikas, P. \& Tchobanoglous, G. 2009 The role of satellite and decentralized strategies in water resources management. Journal of Environmental Management 90 (1), 144-152.

He, P., Phan, L., Gu, G. \& Hervouet, G. 200r Reclaimed municipal wastewater - a potential water resource in China. Water Science and Technology 43 (10), 51-58.

Holland, J. 2007 Tools for Institutional, Political, and Social Analysis of Policy Reform: A Sourcebook for Development Practitioners. World Bank, Washington DC.

Lens, P. \& Lettinga, G. 200I Decentralized Sanitation and Reuse: Concepts, Systems and Implementation. Taylor \& Francis, Abingdon, UK.

Li, L. 2012 Support System and Policy Mechanisms for Diffusion of Environmentally Sound Technology. PhD Thesis, Research Center for Eco-Environmental Sciences, Chinese Academic of Science, Beijing, China (in Chinese).

Markard, J. 20II Transformation of infrastructures: sector characteristics and implications for fundamental change. Journal of Infrastructure Systems 17 (3), 107-117.

Massoud, M. A., Tarhini, A. \& Nasr, J. A. 2009 Decentralized approaches to wastewater treatment and management: applicability in developing countries. Journal of Environmental Management 90, 652-659.

Ministry of Housing and Urban-rural Development of People's Republic of China 2008 Statistic Report of Urban, County and Town Construction. Ministry of Housing and Urban-rural Development of People's Republic of China, Beijing.

Qin, C., Pei, Y. \& Zhang, X. 20Io Water price calculation of Eastern and middle route of South-to-North Water Diversion Project: method and practice. Journal of Economics of Water Resources 28 (5), 33-37(in Chinese).

Sabry, T. 20Io Evaluation of decentralized treatment of sewage employing Upflow Septic Tank/Baffled Reactor (USBR) in developing countries. Journal of Hazardous Materials 174, 500-505.

Tan, Y., Tan, B. \& Wang, Q. 2007 Progress in Seawater desalination projects in China. Technology of Water Treatment 33 (1), 1-3 (in Chinese).

Unruh, G. C. \& Carrillo-Hermosilla, J. 2006 Globalizing carbon lock-in. Energy Policy 34 (10), 1185-1197.

van Voorthuizen, E. M., Zwijnenburg, A. \& Wessling, M. 2005 Nutrient removal by NF and RO membranes in a decentralized sanitation system. Water Research 39 (15), 3657-3667.

Water Environment Research Foundation 2007 Influent Constituent Characteristics of the Modern Waste Stream from Single Sources: Literature Review, Report 04-Dec-1a. Water Environment Research Foundation, Alexandria, VA, USA.

Wilderer, P. A. 2004 Applying sustainable water management concepts in rural and urban areas: some thoughts about reasons, means and needs. Water Science and Technology 49 (7), 8-16. 